$\underline{\text { Araștırma Makalesi }}$

\title{
Ağrı İlinde Üreticilerin Meyve Yetiştirme Kararını Etkileyen Unsurlar ve Geleceğe Yönelik Beklentileri
}

\author{
Arzu SEÇER ${ }^{1 *}, \quad$ Ferdi ÇELİK ${ }^{1}, \quad$ Hatice BARUT ${ }^{1}$
}

\section{ÖZ}

Ağrı ili sosyo-ekonomik açıdan geri kalmış iller arasındadır. Meyve yetiştiriciliğinin kırsal alanda sağlayacağı faydalar dikkate alınarak 2018 yılından bu yana "Meyve Yetiştiriciliği ve Geliştirmesi Projesi" uygulanmaktadır. Ancak, üreticilerin bu projeye katılımları oldukça düşük düzeyde kalmıştır. Bu çalışmada, Ağrı ilinde meyve yetiştiren ve yetiştirmeyen üreticilerin sosyo-ekonomik özelliklerinin, meyve yetiştiriciliğine yönelik kararlarını etkileyen unsurların ve geleceğe yönelik beklentilerinin karşılaştırmalı olarak ortaya konulması amaçlanmıştır. Üreticilerin meyve ağacı yetiştirme kararını etkileyen unsurlar Planlanmış Davranış Teorisi (Theory Planned Behavior) çerçevesinde davranışa yönelik tutumlar, kişisel normlar ve algılanan davranışsal inançları olarak üç başlık altında incelenmiş ve ele alınan unsurların pek çoğunda gruplar arasında istatistiksel olarak anlamlı farklılık bulunmuştur. Bununla beraber, elde edilen bulgular üreticilerin üretim, pazarlama ve uygulanan destekler konusunda bilgi yetersizliği olduğunu göstermektedir. Araştırma bölgesinde meyveciliği geliştirmek amacıyla üreticilerin engel olarak ifade ettiği unsurlar esas alınarak bütünsel bir yaklaşım içerisinde eğitim çalışmaları düzenlenmelidir.

Anahtar Kelimeler: Meyve yetiştiriciliği kararı, planlanmış davranış teorisi, Ağrı.

\section{The Factors Affecting the Producers' Decision to Grow Fruit Tree and Their Expectations for the Future in Ağrı Province}

\begin{abstract}
Ağr province is among the socio-economically underdeveloped provinces. Considering the benefits of fruit growing in rural areas, the "Fruit Growing and Development Project in Ağrr" has been implemented since 2018. However, the participation of farmers in this project remained at a low level. In this study, it was aimed to reveal the socio-economic characteristics of the producers who grow fruit trees and those who do not, in comparison with the factors affecting their intention towards fruit growing and their future expectations. The factors affecting the producers' decision to grow the fruit tree were examined under three headings as subjective attitudes, subjective norms and perceived control beliefs within the framework of the planned behaviour theory, and statistically significant differences were found between the groups in most of the considered elements. However, the findings show that the farmers have lack of knowledge about production, marketing and applied supports. In order to develop fruit growing in this province, training activities should be organized in a holistic approach, based on the factors expressed as obstacles by producers.
\end{abstract}

Keywords: Fruit growing decision, theory of planned behaviour, Ağrı.

ORCID ID (Yazar sirasına göre)

0000-0003-1347-4988, 0000-0001-8272-4720, 0000-0002-8129-7576

Yayın Kuruluna Geliş Tarihi: 13.11.2020

Kabul Tarihi: 16.12.2020

${ }^{1}$ Çukurova Üniversitesi, Ziraat Fakültesi, Tarım Ekonomisi Bölümü, Sarıçam, Adana

*E-posta: asecer@cu.edu.tr 


\section{Ağrı İlinde Üreticilerin Meyve Yetiştirme Kararını Etkileyen Unsurlar ve Geleceğe Yönelik Beklentileri}

\section{Giriș}

Ağrı ili sosyo-ekonomik gelişmişlik düzeyi açısından Türkiye'nin en geri kalmış illeri arasında yer almaktadır. Bu ilde GSYIH'nın \%22.4'ü tarım, \%11.7'si sanayi ve \%56.5'i hizmet sektörlerinden elde edilmektedir. Türkiye'de ise tarım sektörünün toplam GSYİH içerisinde payı sadece \%5,8'dir. Bu sebeple Ağr1 ilinde temel geçim kaynağının tarım olduğu söylenebilir. Tarım ürünleri içerisinde ise özellikle tahıllar, yem bitkileri ve hayvansal üretim yapılmaktadır (TUIK 2020).

Meyve yetiştiriciliğinin üreticilere ekonomik, sosyal ve çevresel açıdan çok sayıda faydası vardır. Ekonomik olarak üreticilerin gelir artış1 sağlaması, atıl işgücü için istihdam olanağ yaratması ve ailelerin g1da güvenliğini sağlaması oldukça önemli faydaları arasındadır. Sosyal olarak ağaç yetiştirmek önemli ölçüde toplumun farklı yaş ve cinsiyetlerinden bireyleri bir araya getirerek sorumluluk paylaşımını ve toplumsal olarak yeni bir kimlik ve aidiyet duygusunun oluşmasını sağlamaktadır. Çevresel açıdan ise ağaç yetiştirmek biyoçeşitliliği artırmakta, sera gazı etkisini azaltmakta, erozyonu önlemekte ve toprağın su kalitesini artırmakta önemli rol oynamaktadır (Nowak ve ark 2010; TPO 2012)

Ağrı ilinde 2018 yılından bu yana tarımsal ürün çeșitliliğinin artırılması, bölgenin meyve ihtiyacının karşılanmasını ve üreticinin gelir seviyesinin artırılmasi amaciyla "Meyve Yetiştiriciliği ve Geliştirmesi Projesi" uygulanmaktadır. Bu proje uzun vadede; ilde yaş meyveye yönelik bir pazarlama zincirinin oluşması, üretime paralel olarak soğuk hava depolarının yaygınlaşması, nakliye ve hizmet sektörlerinin (budama, toplama, ambalaj vb.) gelişmesi ve böylece bir bütün olarak Ağrı ilinin kalkınmasına katkıda bulunacaktır. Bu proje kapsamında 2018-2020 yılları arasinda toplam 350 üreticiye (2018'de 50 adet üretici; 2019'da 100 adet üretici; 2020 'de 150 adet üretici). Kapalı meyve bahçesi yapılması şartıyla meyve fidanı dağıtımı gerçekleştirilmiştir. Böylece 2018 yılı öncesinde meyve ağacı yetiştirilen alan 600 dekar iken 2020 yılında 6500 dekara ulaşmıştır (TOB 2020).

Son yıllarda Ağnı ilinde üreticilerin meyve yetiştiriciliğine eğilim göstermesine rağmen, literatürde bu eğilimde etkili olan faktörleri araştıran akademik bir çalışmaya rastlanmamıștır. Üreticilerin ürün desenlerini değiştirirken bazı endişelerinin olduğu ve meyve ağacı yetiştirmek isteyen üretici sayısının kısıtlı kaldığ1 gözlenmektedir. $\mathrm{Bu}$ bakımdan üreticilerin meyve yetiştiriciliği ile ilgili tutumlarının ortaya konulması oldukça önemlidir. Bu çalışma ile Ağrı ilinde meyve yetiştiren ve yetiştirmeyen üreticilerin sosyoekonomik özelliklerini; planlı davranış teorisi çerçevesinde meyve yetiştiriciliğine yönelik tutumlarını (sübjektif tutumlar, kişisel normlar ve algılanan davranışsal kontrol olarak) ve geleceğe yönelik beklentilerini karşılaştırmalı olarak ortaya koyulması amaçlanmıştır.

\section{Materyal ve Yöntem}

Kuramsal Çerçeve: $\mathrm{Bu}$ çalışmada üreticilerin meyve ağacı yetiştirmeye yönelik niyetlerini etkileyen unsurlar Ajzen'in Planlanmış Davranış Teorisi temel alınarak ortaya konulmuştur. Planlanmış davranış teorisine göre, bir davranışın gerçekleşebilmesi için öncelikle o davranışa yönelik niyetin oluşması gerekmektedir. $\mathrm{Bu}$ teorinin davranışsal niyeti tahmin etmek için üç bileşeni bulunmaktadır. Davranışsal niyet insanların bir davranışı gerçekleştirmek için bu davranışı etkileyen motivasyon unsurları gözlemlenerek tahmin edilmektedir. Bu unsurlardan birincisi davranışa yönelik tutum olup davranışı sergileyecek olan kişinin, gerçekleştirilecek davranışı iyi veya kötü olarak değerlendirmesi olarak açıklanmaktadır. İkinci unsur kişisel normlardır ve davranış1 yapacak olan kişi için önemli olan motivasyonun kişilerin (referans kişiler), kurum veya kuruluşların belirli bir davranışın gerçekleşmesi ya da gerçekleşmemesi ile ilgili beklentileri olduğunu ifade etmektedir. Üçüncü unsur ise varsayılan davranış kontrolü olup davranışı gösterecek kişinin söz konusu davranış1 sergileyebilmesinin ne derece kolay veya zor olacağına inancını göstermektedir (Ajzen 1991).

Planlanmış davranış teorisi aslında sosyal psikolojide yaygın olarak kullanılan bir kuram olmakla birlikte, birçok farklı disiplinin alanına giren davranışları açıklamada da sıklıkla kullanılmıştır (Erten, 2002; Stefan 2013; Bozkurt 2014; Yılmaz ve Doğan 2016; Setti 


\section{Ağrı İlinde Üreticilerin Meyve Yetiştirme Kararını Etkileyen Unsurlar ve Geleceğe Yönelik Beklentileri}

2016; Onur ve Kırıkc1 2018; Aktas ve ark 2018). $\mathrm{Bu}$ çalışma, planlanmış davranış teorisini bir çerçeve olarak kullanarak meyve ağacı yetiştiren ve yetiştirmeyen üreticilerin meyve ağac1 yetiştirmeye yönelik kararlarını etkileyen unsurları karşılaştırmalı olarak sunmaktadır.

Materyal: Çalışmanın ana materyali, Ağrı ilinde "Meyve Yetiştiriciliği ve Geliştirmesi Projesi" projesi kapsamında kapalı bahçede meyve yetiştiriciliği yapan ve yapmayan üreticilerden yüz yüze anket yöntemiyle elde edilen birincil verilerden oluşmaktadır.

Anket uygulaması Ağrı Merkez, Tutak, Diyadin ve Doğubeyazıt ilçelerinde gerçekleştirilmiştir. Çalışma kapsamında gönüllülük esasıyla ve tesadüfi olarak seçilen toplam 183 adet üretici ile görüşme yapılmıştır. Bu üreticilerin 103'ü kapalı meyve bahçesi sahibi olup, 80'i ise meyve yetiştiriciliği yapmamaktadır. Anket uygulaması Ağrı İl Tarım ve Orman Müdürlüğü personeli tarafindan gerçekleştirilmiştir.

Çalışmada kullanılan anket formu 3 bölümden oluşmaktadır. Birinci bölümde üreticilerin sosyo-ekonomik yapılarını, ikinci bölümde meyve ağacı yetiştirme kararlarını etkileyen unsurlar1 ve üçüncü bölümde ise geleceğe yönelik beklentilerini ortaya koymaya yönelik sorular sorulmuştur. Üreticilerin meyve ağac1 yetiştirmeye yönelik kararlarını etkileyen unsurları ortaya koymak amaciyla Meijer (2015) tarafindan planlı davranış teorisi dikkate alarak geliştirilen ve 23 maddeyi içeren 5'li likert ölçeği kullanılmıştır. Ölçekte yer alan ancak yörede meyve yetiştiriciliği için uygun olmayacağ 1 düşünülen 3 madde çıkarılmış ("Arazimde meyve ağacı yetiştirmek yakacak odun sağlamada faydalı olacaktır", "Arazimde meyve ağacı yetiştirmek kereste sağlamamda faydalı olacaktır" ve "Çiftliğime ağaç dikmenin sağladığı gölge, mahsulün büyümesini engelliyor" ve sorulması gerektiği düşünülen 3 madde ("Meyve fidanlarının bakımı zor olmaktadı", "Meyve fidanlarının bakımı zor olmaktadır", "Meyve ağaçları ürün verene kadar geçen süre uzun olmaktadır" ve "Meyve ağac1 yetiştirmek arazimde çok fazla yer kaplamaktadır”) eklenmiştir. Bu ölçeğe ek olarak üreticilerin ekonomik açıdan tutumları ise araştırmacılar tarafından geliştirilen 4 madde ile belirlenmiştir.

Verilerin Analizinde Kullanılan Yöntem: Alan çalışması sonucu elde edilen veriler frekans oran ve ortalamalar hesaplanarak sunulmuştur. Gruplar arası karşılaştırmalarda $t$ testinden yararlanılmıştır.

\section{Araştırma Bulguları}

Üreticilere İlişkin Bilgiler: Araştırma alanında üreticilerin ortalama yaşı 44.7 olup bu rakam meyve yetiştiren işletmecilerde 43.8 ve yetiştirmeyen işletmecilerde $45.9^{\prime}$ dur. $\mathrm{Bu}$ kişilerin eğitim süresi ortalama 6.3 yildır ve bu süre meyve yetiştiren işletmecilerde 6.6 yıl iken yetiştirmeyenlerde 5.8 yıl olarak hesaplanmıştır. Hane halkı genişliği ise ortalama 6.8 kişidir (Çizelge 1).

Çizelge 1. Üreticilerin Demografik özellikleri

\begin{tabular}{|c|c|c|c|c|c|c|}
\hline \multirow[t]{2}{*}{$\begin{array}{l}\text { Demografik } \\
\text { Özellikler }\end{array}$} & \multicolumn{2}{|c|}{$\begin{array}{l}\text { Meyve Yetiştiren } \\
\text { Üreticiler }\end{array}$} & \multicolumn{2}{|c|}{$\begin{array}{c}\text { Meyve } \\
\text { Yetiştirmeyen } \\
\text { Üreticiler }\end{array}$} & \multicolumn{2}{|c|}{ Toplam } \\
\hline & adet & $\%$ & adet & $\%$ & adet & $\%$ \\
\hline \multicolumn{7}{|c|}{ Yas } \\
\hline$<40$ & 34 & 33.0 & 22 & 27.5 & 56 & 30.6 \\
\hline $40-50$ & 49 & 47.6 & 33 & 41.2 & 82 & 44.8 \\
\hline $50>$ & 20 & 19.4 & 25 & 31.2 & 45 & 24.6 \\
\hline Toplam & 103 & 100.0 & 80 & 100.0 & 183 & 100.0 \\
\hline Ortalama & \multicolumn{2}{|c|}{43.8 y1l } & \multicolumn{2}{|c|}{$45.9 \mathrm{y} 1 \mathrm{l}$} & \multicolumn{2}{|c|}{$44.7 \mathrm{y} 1 \mathrm{l}$} \\
\hline \multicolumn{7}{|l|}{ Eğitim Düzeyi } \\
\hline Okur Yazar Değil & 3 & 2.9 & 7 & 8.8 & 10 & 5.5 \\
\hline Okur Yazar & 18 & 17.5 & 13 & 16.2 & 31 & 16.9 \\
\hline İlkokul Mezunu & 36 & 35.0 & 33 & 41.2 & 69 & 37.7 \\
\hline
\end{tabular}


Çizelge 1. Devam

\begin{tabular}{|l|c|c|c|c|c|c|}
\hline Ortaokul Mezunu & 26 & 25.2 & 13 & 16.2 & 39 & 21.3 \\
\hline Lise Mezunu & 14 & 13.6 & 13 & 16.2 & 27 & 14.8 \\
\hline Üniversite Mezunu & 6 & 5.8 & 1 & 1.2 & 7 & 3.8 \\
\hline Toplam & 103 & 100.0 & 80 & 100.0 & 183 & 100.0 \\
\hline Ortalama & \multicolumn{7}{|c|}{6.6 yıl } & \multicolumn{2}{c|}{5.8 yıl } & \multicolumn{2}{c|}{6.3 yıl } \\
\hline \multicolumn{7}{|c|}{ Hanehalkı Genişliği } \\
\hline$\leq 6$ & 61 & 59.2 & 35 & 43.8 & 96 & 52.5 \\
\hline $6>$ & 42 & 40.8 & 45 & 56.2 & 87 & 47.5 \\
\hline Toplam & 103 & 100.0 & 80 & 100.0 & 183 & 100.0 \\
\hline Ortalama & 6.7 kişi & \multicolumn{2}{c|}{7.0 kişi } & \multicolumn{2}{c|}{6.8 kişi } \\
\hline
\end{tabular}

İşletmecilerin tarımsal üretim deneyimleri ortalama 15.3 yıl olup bu süre meyve ağacı yetiştirenlerde 13,0 yıl iken yetiştirmeyenlerde 18.2 yıldır. İşletmecilerin meyve ağacı yetiştirme süresi ise ortalama 2.56 yıldır.

Görüşülen kişilerin \%95.1'i tarımsal eğitim aldıklarını ifade etmişlerdir (meyve ağacı yetiştirenlerin \%92.2'si; yetiştirmeyenlerin \%98.8'i). Bu kişilerin \%97.8'i tarımsal örgüte üye durumda olup (meyve ağacı yetiştirenlerin
$\% 98.1$ 'i; yetiştirmeyenlerin $\% 97.5$ 'i) $\% 80.3$ 'ü ise tarım dışı iş sahibidir (meyve ağacı yetiştirenlerin \%81.6's1; yetiştirmeyenlerin $\% 78.8^{\prime} i$ ).

İşletmelere İlişsin Bilgiler: İşletmelerde üretilen en önemli tarla bitkileri buğday (91.6 da), arpa (59.6 da), yonca (77.1 da), korunga $(55.2 \mathrm{da})$ ve fiğdir $(20.0 \mathrm{da})$. Görüşülen işletmelerde üretilen bahçe bitkileri ise erik (20.0 da), kayıs1 (9.6 da), ceviz (8.1 da) ve elmadır (6.4 da) (Çizelge 2).

Çizelge 2. İşletmelerde Ürün Deseni (da)

\begin{tabular}{|l|r|r|r|}
\hline \multicolumn{1}{|c|}{ Ürünler } & $\begin{array}{c}\text { Meyve } \\
\text { Ağac1 } \\
\text { Yetiştirilen } \\
\text { İşletmeler }\end{array}$ & $\begin{array}{c}\text { Meyve } \\
\text { Ağac1 } \\
\text { Yetiştirilmeyen } \\
\text { İşletmeler }\end{array}$ & Genel \\
\hline Buğday & 81.3 & 100.2 & 91.6 \\
\hline Arpa & 61.1 & 58.5 & 59.6 \\
\hline Yonca & 93.2 & 60.5 & 77.1 \\
\hline Korunga & 67.5 & 45.3 & 55.2 \\
\hline Fiğ & 30.2 & 23.0 & 28.1 \\
\hline Erik & 20.0 & - & 20.0 \\
\hline Kayisi & 9.6 & - & 9.6 \\
\hline Ceviz & 8.1 & - & 8.1 \\
\hline Elma & 6.4 & - & 6.4 \\
\hline Armut & 6.5 & - & 6.5 \\
\hline Diğgr* & 9.0 & & 9.0 \\
\hline
\end{tabular}

*Diğer: Kiraz, patates, kavun ve karpuz.

Ele alınan işletmelerde parsel sayısı buğdayda 3.9 adet, arpada 3.2 adet, yoncada 2.7 adet ve fiğde 1.7 adettir. Bahçe bitkilerinde parsel sayısı ise elmada 1.0 adet, cevizde 1.3 adet ve armutta 1.3 adettir (Çizelge 3 ). 
Çizelge 3. İşletmelerde Parsel Sayısı (adet)

\begin{tabular}{|l|l|l|l|}
\hline & $\begin{array}{l}\text { Meyve } \\
\text { Ağac1 } \\
\text { Yetiştirilen } \\
\text { İşletmeler }\end{array}$ & $\begin{array}{l}\text { Meyve } \\
\text { Ağaci } \\
\text { Yetiştirilmeyen } \\
\text { İşletmeler }\end{array}$ & Genel \\
\hline Buğday & 3.1 & 4.6 & 3.9 \\
\hline Arpa & 2.5 & 3.7 & 3.2 \\
\hline Yonca & 2.6 & 2.8 & 2.7 \\
\hline Korunga & 2.3 & 2.2 & 2.3 \\
\hline Fig & 2.0 & 1.0 & 1.7 \\
\hline Elma & 1.0 & - & 1.0 \\
\hline Ceviz & 1.3 & - & 1.3 \\
\hline Armut & 1.3 & - & 1.3 \\
\hline Erik & 2.5 & - & 2.5 \\
\hline Kay1s1 & 1.0 & - & 1.0 \\
\hline Diğer* & 4 & & 4 \\
\hline
\end{tabular}

*Diğer: Kiraz, patates, kavun ve karpuz.

İşletmelerde yetiştirilen ürünlerde parsel genişliği buğdayda 23.5 da, arpada 18.6 da, 16.5 da'dır. Ortalama parsel meyve bahçelerinde elmada 20.0 da, cevizde 7.4 da, kirazda 6.5 da ve yoncada 28.6 da, korungada 24.0 da ve fiğgde armutta 6.2 da olarak hesaplanmıştır (Çizelge 4).

Çizelge 4. İşletmelerde parsel genişliği (da)

\begin{tabular}{|c|c|c|c|}
\hline Ürünler & $\begin{array}{c}\text { Meyve } \\
\text { Yetiştirilen } \\
\text { İşletmeler }\end{array}$ & $\begin{array}{c}\text { Meyve } \\
\text { Yetiştirilmeyen } \\
\text { İşletmeler }\end{array}$ & Genel \\
\hline Buğday & 26.2 & 21.8 & 23.5 \\
\hline Arpa & 24.4 & 15.8 & 18.6 \\
\hline Yonca & 35.8 & 21.6 & 28.6 \\
\hline Korunga & 29.3 & 20.6 & 24.0 \\
\hline Fig & 15.1 & 23.0 & 16.5 \\
\hline Elma & 20.0 & - & 20.0 \\
\hline Ceviz & 7.4 & - & 7.4 \\
\hline Kiraz & 6.5 & - & 6.5 \\
\hline Armut & 6.2 & - & 6.2 \\
\hline Patates & 5.0 & - & 5.0 \\
\hline Diğer* & 1.7 & & 1.7 \\
\hline
\end{tabular}

*Diğer: Kiraz, patates, kavun ve karpuz.

Üreticilerin meyve ağacı yetiştirme kararını etkileyen unsurlar: Üreticilerin meyve ağacı yetiştirmeye yönelik en önemli kişisel inançları meyve ağac1 yetiştiren üreticilerde "Meyve yetiştirmek gelirimi artıracaktır" (ort: 4.3), "Meyve ağaçları ürün verene kadar geçen süre uzun olmaktadır" (ort: 4.3), "Meyve ağacı yetiştirmek boş araziyi değerlendirmek açısından önemlidir" (ort: 4.3) ve "Köydeki ürün çeşitliliğinin artması benim için önemlidir" (ort:
4.3); meyve ağac1 yetiştirmeyenlerde ise "Meyve ağaçları ürün verene kadar geçen süre uzun olmaktadır" (ort: 4.4), "Meyve ağac1 yetiştirmek arazimde sulama suyu kitlığına sebep olacaktır" (ort: 4.3) ve "Meyve fidanlarının bakımı zor olmaktadır" (ort: 4.2) şeklindedir. Meyve yetiştiren ve yetiştirmeyen üreticiler arasında çoğu ifade bakımından istatistiksel olarak anlamlı farklılık bulunmaktadır. 


\section{Ağrı İlinde Üreticilerin Meyve Yetiştirme Kararını Etkileyen Unsurlar ve Geleceğe Yönelik Beklentileri}

Görüșülen üreticilerin meyve yetiștirme kararını etkileyen en önemli kişisel normlar ise meyve yetiştiren üreticilerde "Ailem meyve ağac1 yetiştirmem gerektiğini düşünür" (ort: 4.2); meyve yetiştirmeyenlerde ise "Kamu kurumları meyve ağacı yetiştirmem gerektiğini düşünür" (ort: 2.4) olarak belirlenmiştir. Gruplar arasında tüm ifadelerde istatistiksel olarak anlamlı farklılık bulunmaktadır.

Üreticilerin meyve yetiştiriciliğine karşı en önemsedikleri davranışsal kontrol unsurları ise "Arazimle ilgili tüm işleri yapmak için yeterli zamanım var" (ort: 4.0) ve "Meyve bahçelerinde sulama suyuna kolayca erişim sağlanabilmektedir" (ort: 4.0) olurken meyve ağacı yetiştirmeyenlerde "Yörede iklim koşulları meyve yetiştiriciliği için uygun değildir" (ort: 4.3) ve "Arazimde hayvanların otlatılması riski sebebiyle meyve ağacı yetiştirmek zor olabilir" (4.3) şeklindedir. Meyve ağacı yetiştiren ve yetiştirmeyen üreticiler arasında çoğu ifade bakımından istatistiksel olarak anlamlı farklılık bulunmaktadır (Çizelge 5).

Çizelge 5. Üreticilerin meyve ağacı yetiştirme kararını etkileyen unsurlar*

\begin{tabular}{|c|c|c|c|c|c|c|c|}
\hline \multirow{2}{*}{ Unsurlar } & \multicolumn{2}{|c|}{$\begin{array}{c}\text { Meyve } \\
\text { Yetiştiren } \\
\text { Üreticiler } \\
\end{array}$} & \multicolumn{2}{|c|}{$\begin{array}{c}\text { Meyve } \\
\text { Yetiştirmeyen } \\
\text { Üreticiler }\end{array}$} & \multicolumn{2}{|c|}{$\begin{array}{l}\text { Tüm } \\
\text { Üreticiler }\end{array}$} & \multirow[t]{2}{*}{$\mathrm{p}$} \\
\hline & Ort. & SD & Ort. & $\mathrm{SD}$ & Ort. & SD & \\
\hline Meyve yetiştirmek gelirimi artıracaktır. & 4.3 & 0.7 & 2.8 & 1.1 & 3.7 & 1.2 & 0.000 \\
\hline $\begin{array}{l}\text { Meyve yetiştirmek aile tüketimini karşılamada önemli } \\
\text { bir kaynaktır. }\end{array}$ & 4.2 & 0.7 & 2.7 & 1.0 & 3.6 & 1.1 & 0.000 \\
\hline $\begin{array}{l}\text { Meyve ağacından elde edilen atıklar (budanan kısımlar, } \\
\text { kabuklar vs) yakacak ihtiyacımı karşımada önemlidir. }\end{array}$ & 4.1 & 0.9 & 2.2 & 1.5 & 3.3 & 1.5 & 0.000 \\
\hline $\begin{array}{l}\text { Meyve ağacı yetiştirmek toprak verimliliğimi } \\
\text { artıracaktır. }\end{array}$ & 4.2 & 0.7 & 2.7 & 1.1 & 3.6 & 1.2 & 0.000 \\
\hline $\begin{array}{l}\text { Meyve ağacı yetiştirmek hastalık ve zararlıların } \\
\text { yayılmasını artırır. }\end{array}$ & 4.2 & 0.8 & 3.5 & 1.1 & 3.9 & 1.0 & 0.000 \\
\hline Meyve fidanlarının bakımı zor olmaktadır. & 4.1 & 0.8 & 4.4 & 0.9 & 4.2 & 0.9 & 0.048 \\
\hline $\begin{array}{l}\text { Meyve ağaçları ürün verene kadar geçen süre uzun } \\
\text { olmaktadır. }\end{array}$ & 4.3 & 0.8 & 4.6 & 0.8 & 4.4 & 0.8 & 0.003 \\
\hline $\begin{array}{l}\text { Meyve ağacı yetiştirmek arazimde çok fazla yer } \\
\text { kaplamaktadır. }\end{array}$ & 4.2 & 0.9 & 3.7 & 0.8 & 4.0 & 0.9 & 0.001 \\
\hline $\begin{array}{l}\text { Meyve ağacı yetiştirmek arazimde sulama suyu kıtlığına } \\
\text { sebep olacaktır. }\end{array}$ & 4.2 & 0.9 & 4.5 & 5.8 & 4.3 & 3.9 & 0.131 \\
\hline $\begin{array}{l}\text { Meyve ağacı yetiştirmek boş araziyi değerlendirmek } \\
\text { açısından önemlidir. }\end{array}$ & 4.3 & 0.8 & 3.0 & 1.2 & 3.7 & 1.2 & 0.000 \\
\hline Köydeki ürün çeşitliliğinin artması benim için önemlidir. & 4.3 & 0.8 & 2.9 & 1.1 & 3.7 & 1.2 & 0.000 \\
\hline \multicolumn{8}{|l|}{ Kişisel Normlar } \\
\hline Ailem meyve ağacı yetiştirmem gerektiğini düşünür. & 4.2 & 1.0 & 2.2 & 1.5 & 3.3 & 1.6 & 0.000 \\
\hline $\begin{array}{l}\text { Diğer çiftçiler meyve ağacı yetiştirmem gerektiğini } \\
\text { düşünür. }\end{array}$ & 3.6 & 1.1 & 1.9 & 1.3 & 2.9 & 1.5 & 0.000 \\
\hline $\begin{array}{l}\text { Yayım elemanları meyve ağacı yetiştirmem gerektiğini } \\
\text { düşünür. }\end{array}$ & 3.7 & 1.1 & 2.2 & 1.5 & 3.0 & 1.5 & 0.000 \\
\hline $\begin{array}{l}\text { Kamu kurumları meyve ağacı yetiştirmem gerektiğini } \\
\text { düşünür. }\end{array}$ & 3.7 & 1.1 & 2.4 & 1.6 & 3.1 & 1.5 & 0.000 \\
\hline $\begin{array}{l}\text { Köyün önde gelenleri meyve ağacı yetiştirmem } \\
\text { gerektiğini düşünür. }\end{array}$ & 3.5 & 1.1 & 2.0 & 1.4 & 2.8 & 1.4 & 0.000 \\
\hline
\end{tabular}




\section{Ağrı İlinde Üreticilerin Meyve Yetiștirme Kararını Etkileyen Unsurlar ve Geleceğe Yönelik Beklentileri}

Çizelge 5. Devam

\begin{tabular}{|c|c|c|c|c|c|c|c|}
\hline 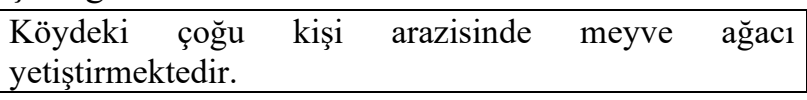 & 3.3 & 1.2 & 1.6 & 1.2 & 2.6 & 1.5 & 0.000 \\
\hline \multicolumn{8}{|l|}{ Algılanan Davranısssal Kontrol } \\
\hline $\begin{array}{l}\text { Arazimde sık sık hastalık ve zararlılarla ilgili sorun } \\
\text { yaşarım. }\end{array}$ & 3.5 & 1.1 & 3.1 & 0.8 & 3.3 & 1.0 & 0.012 \\
\hline Yörede genellikle yağışlar düzensiz ve yetersizdir. & 3.5 & 1.1 & 3.5 & 0.9 & 3.5 & 1.0 & 0.753 \\
\hline $\begin{array}{l}\text { Yörede iklim koşulları meyve yetiştiriciliği için uygun } \\
\text { değildir. }\end{array}$ & 3.5 & 1.1 & 4.3 & 1.1 & 3.8 & 1.2 & 0.000 \\
\hline $\begin{array}{l}\text { Arazimde hayvanların otlatılması riski sebebiyle meyve } \\
\text { ağacı yetiştirmek zor olabilir. }\end{array}$ & 3.6 & 1.2 & 4.3 & 1.1 & 3.9 & 1.2 & 0.000 \\
\hline $\begin{array}{l}\text { Arazimle ilgili tüm işleri yapmak için yeterli zamanım } \\
\text { var. }\end{array}$ & 4.0 & 1.0 & 2.8 & 1.1 & 3.4 & 1.2 & 0.000 \\
\hline Meyve ağacı fidanlarına kolayca ulaşılabilmektedir & 3.9 & 1.1 & 2.5 & 1. & 3.3 & 1.3 & 0.000 \\
\hline $\begin{array}{l}\text { Meyve bahçelerinde sulama suyuna kolayca erişim } \\
\text { sağlanabilmektedir. }\end{array}$ & 4.0 & 1.1 & 3.1 & 0.9 & 3.6 & 1.1 & 0.000 \\
\hline
\end{tabular}

* Üreticilerin meyve ağacı yetiştirmeye yönelik kararlarını etkileyen unsurlar Ek Çizelge 1 ve Ek Çizelge 2'de ayrıntılı şekilde sunulmuştur.

Üreticilerin Meyve Ağacı Yetiştirmesini Etkileyen Ekonomik Unsurlar: Araştırma alanında meyve ağacı yetiştirmeyen üreticilerin, yetiştiren üreticilere göre ekonomik unsurları daha yüksek düzeyde önemli bulmaktadır. Meyve ağac1 yetiştirenlerde en önemli unsurlar "Meyve ağac1 yetiştirmek arazimdeki üretim kurmanın maliyeti yüksektir." (ort: 3.7); meyve ağac1 yetiştirmeyenlerde "Meyve ağac1 yetiştirmek daha fazla sayıda girdi gerektirmektedir." (ort: 4.5), "Meyve ağac1 yetiştirmek daha fazla işgücü gerektirmektedir." (ort: 4.5). Gruplar arasinda tüm ifadelerde istatistiksel olarak anlamlı farkl111k bulunmaktadır (Çizelge 6). masraflarını artıracaktır" (ort: 3.7), "Bahçe tesisi

Çizelge 6. Üreticilerin Meyve Ağacı Yetiştirmesini Etkileyen Ekonomik Unsurlar

\begin{tabular}{|c|c|c|c|c|c|c|c|}
\hline \multirow[t]{2}{*}{ İfadeler } & \multicolumn{2}{|c|}{$\begin{array}{l}\text { Meyve } \\
\text { Yetiştiren } \\
\text { Üreticiler }\end{array}$} & \multicolumn{2}{|c|}{$\begin{array}{c}\text { Meyve } \\
\text { Yetiştirmeyen } \\
\text { Üreticiler }\end{array}$} & \multicolumn{2}{|c|}{$\begin{array}{l}\text { Tüm } \\
\text { Üreticiler }\end{array}$} & \multirow[t]{2}{*}{$\mathrm{p}$} \\
\hline & $\mathrm{M}$ & SD & $\mathrm{M}$ & $\mathrm{SD}$ & $\mathrm{M}$ & SD & \\
\hline $\begin{array}{llll}\text { Meyve ağacı yetiştirmek } & \text { arazimdeki } & \text { üretim } \\
\text { masraflarını artıracaktır }\end{array}$ & 3.7 & 1.0 & 4.4 & 0.9 & 4.0 & 1.0 & 0.000 \\
\hline $\begin{array}{l}\text { Meyve ağacı yetiştirmek daha fazla sayıda girdi } \\
\text { gerektirmektedir. }\end{array}$ & 3.5 & 1.2 & 4.5 & 0.8 & 3.9 & 1.2 & 0.000 \\
\hline $\begin{array}{l}\text { Meyve ağacı yetiştirmek daha fazla işgücü } \\
\text { gerektirmektedir. }\end{array}$ & 3.6 & 1.2 & 4.5 & 0.9 & 4.0 & 1.2 & 0.000 \\
\hline Bahçe tesisi kurmanın maliyeti yüksektir. & 3.7 & 1.0 & 4.4 & 0.9 & 4.0 & 1.0 & 0.000 \\
\hline
\end{tabular}

Üreticilerin Meyve Ağacı Yetiştirmekle İlgili Geleceğe Yönelik Beklentileri: Meyve ağacı yetiştiren üreticilerin $\% 77.4$ 'ü bu faaliyetlerine devam etmeyi düşünmektedir. Araştırma alanında meyve yetiştiriciliği üreticiler tarafindan henüz benimsenmeye başlamıştır. $\mathrm{Bu}$ sebeple, meyve ağacı yetiştirmeyenlerin sadece \%22.6's1 gelecekte meyve bahçesi tesis etmeyi düşünmektedir. Gelecekte yetiştirilmesi düşünülen başlıca ürünler ise elma (\%59.1), kayıs1 (\%16.5), ceviz (\%13.0), armut (\%7.8) ve diğer ürünlerdir (erik, kiraz, ejder meyvesi; \%3.6).

Üreticiler meyve yetiştiriciliğine verilecek desteklerin önemli olduğunu ve gelecekte özellikle bahçe tesisine, üretilen ürüne ve ziraat mühendisliği ya da tarım danışmanlığına desteklerin devam etmesinin verilmesinin 


\section{Ağrı İlinde Üreticilerin Meyve Yetiştirme Kararını Etkileyen Unsurlar ve Geleceğe Yönelik Beklentileri}

üretimi teşvik edeceğini ifade etmişlerdir (Çizelge 7).

Çizelge 7. Üreticilerin Meyve Ağacı Yetiştirmek için Verilmesini Talep Ettikleri Destekler

\begin{tabular}{|c|c|c|}
\hline Destekler & $\mathrm{N}$ & $\%$ \\
\hline Bahçe tesisine destek & 93 & 80.9 \\
\hline Üretilen ürüne destek & 52 & 45.2 \\
\hline Ziraat mühendisi tarım danışmanı desteği & 81 & 70.4 \\
\hline Alet ekipman desteği & 31 & 27.0 \\
\hline Mazot ve gübre desteği & 42 & 36.5 \\
\hline Sulama suyu temininin sağlanması & 66 & 57.4 \\
\hline Sulama suyunun desteklenmesi & 40 & 34.8 \\
\hline
\end{tabular}

\section{Sonuç ve Öneriler}

Ağrı ilinde temel geçim kaynağı tarım olup yetiştirilen başlıca ürünler tahıllar ve yem bitkileridir. Meyve yetiştiriciliğinin üreticilere sağlayacağı ekonomik, sosyal ve çevresel faydalar göz önüne alınarak 2018 yılından bu yana "Meyve Yetiştiriciliği ve Geliştirmesi Projesi" uygulanmaktadır. Bu proje kapsamında 2020 y1lı itibariyle 300 adet üretici 6500 dekara alanda meyve ağacı yetiştirmektedir. Bu çalışma ile Ağrn ilinde meyve yetiştiren ve yetiştirmeyen üreticilerin karşılaştırmalı olarak sosyoekonomik özelliklerinin, meyve ağacı yetiştirme kararlarını etkileyen unsurlarının ve geleceğe yönelik beklentilerinin ortaya konulması amaçlanmıştır.

Üreticilerin meyve ağacı yetiştirmeye yönelik niyetlerini etkileyen unsurlar planlanmış teorisi çerçevesinde davranışa yönelik tutumlar, kişisel normlar ve algılanan davranışsal kontrol şeklinde üç başlık altında ele alınmıştır.

Meyve yetiştiren üreticiler meyve yetiştirmenin gelirlerini artıracağını ve boş araziyi değerlendirmelerinde fayda sağlayacağına inanırken aynı zamanda meyve ağaçlarının ürün vermesine kadar geçen sürenin uzun olduğu düşüncesindedir. Bununla beraber bu üreticiler bu faaliyet dalının hastalık ve zararlıların yayılmasını artırdığına, arazide çok fazla yer kapladığına ve sulama suyu kitlığına sebep olacağına inanmaktadır. Meyve ağacı yetiştirmeyenler ise benzer şekilde meyve ağaçlarının ürün vermesine kadar uzun süre geçtiğini, ağaç yetiştirmenin sulama suyu kıtlığına sebep olabileceğini ve fidan bakımının oldukça zor olduğunu ifade etmişlerdir.

Meyve yetiştiren üreticiler ailelerinin; meyve yetiştirmeyen üreticiler ise kamu kurumlarının meyve ağacı yetiştirilmesi konusunda 1srarc1 olduklarını belirtmişlerdir. Meyve ağacı yetiştirmeyenler ise benzer şekilde meyve ağaçlarının ürün vermesine kadar uzun süre geçtiğini, ağaç yetiştirmenin sulama suyu kıtlığına sebep olabileceğini ve fidan bakımının oldukça zor olduğunu ifade etmişlerdir.

Meyve yetiştiren üreticiler ailelerinin; meyve yetiştirmeyen üreticiler ise kamu kurumlarının meyve ağacı yetiştirmeleri konusunda 1 srarc1 olduklarını belirtmişlerdir.

Algılanan Davranışsal Kontrol: Meyve yetiştiren üreticiler meyve yetiştirirken yeterli zamana ve sulama suyuma sahip olduklarını ifade etmişlerdir. $\mathrm{Bu}$ grup yetiştiricilik ile ilgili oldukça pozitif algıya sahiptir. Ancak, meyve ağacı yetiştirmeyenler, iklim koşullarının ve hayvanların otlatılması riskinin kendileri için en büyük engel olduğunu ifade etmişlerdir.

Çalışma kapsamında planlanmış davranış teorisi kapsamında ele alınan unsurlara ek olarak ekonomik unsurlar da değerlendirilmiştir. $\mathrm{Bu}$ faaliyet dalı, meyve yetiştiren üreticiler için daha yüksek üretim masrafı ve bahçe tesisi masrafi; meyve yetiştirmeyen üreticiler içinse daha fazla girdi ve işgücü gerektirmektedir.

Gelecekte, meyve ağacı yetiştiren üreticilerin $\% 77,4$ 'ü bu faaliyetlerine devam etmeyi düşünmekte olup yetiştirmeyen üreticilerin sadece \%22,6's1 meyve bahçesi tesis etmeyi düşünmektedir. Gelecekte yetiştirilmesi 


\section{Ağrı İlinde Üreticilerin Meyve Yetiştirme Kararını Etkileyen Unsurlar ve Geleceğe Yönelik Beklentileri}

düşünülen başlıca ürünler ise elma, kayısı, ceviz, armuttur. Üreticiler özellikle bahçe tesisine, üretilen ürüne ve ziraat mühendisliği ya da tarım Elde edilen bulgular 1şı̆̆ında ilde meyve yetiştiriciliğini artırmak amacıyla aşağıdaki öneriler sunulabilir.

1. İlde üreticilere meyve yetiştiriciliğinin sağlayacağı faydalarla ilgili bilgilendirici tanıtım çalışmaları yapılmalı ve bu çalışmalarda üreticilerin özellikle olumsuz görüşe sahip oldukları hastalık ve zararlı kontrolü, sulama şekilleri, meyve fidanlarının bakımı konularıyla ilgili bilgi vermeye özen gösterilmelidir.

2. Üreticiler açısından diğer kiși, kurum ve kuruluşların konuyla ilgili beklentilerini ifade danışmanlığına destek verilmesinin üretimi teşvik edeceğini ifade etmişlerdir.

eden kişisel normlar oldukça belirleyici olmaktadır. $\mathrm{Bu}$ nedenle, meyve ağacı yetiştirmenin sağlayacağı faydalarla ilgili sadece üreticiler değil, bütünsel bir yaklaşımla tüm köy halk1 ve organizasyonlar bilgilendirilmelidir.

3. Üreticiler Tarım ve Orman Bakanlığı'ndan edinecekleri teşvik ve destekler konusunda bilgilendirilmelidir.

\section{Ek Çizelge}

Çizelge 1. Meyve ağacı yetiștirenlerin Karar Almasını Etkileyen Unsurlar

\begin{tabular}{|c|c|c|c|c|c|c|c|c|c|c|c|c|}
\hline \multirow{2}{*}{ Subjektif İnançlar } & \multicolumn{2}{|c|}{1} & \multicolumn{2}{|c|}{2} & \multicolumn{2}{|c|}{3} & \multicolumn{2}{|c|}{4} & \multicolumn{2}{|c|}{5} & \multicolumn{2}{|c|}{ Toplam } \\
\hline & $\mathrm{f}$ & $\%$ & $\mathrm{f}$ & $\%$ & $\mathrm{f}$ & $\%$ & $\mathrm{f}$ & $\%$ & $\mathrm{f}$ & $\%$ & $\mathrm{f}$ & $\%$ \\
\hline $\begin{array}{l}\text { Meyve yetiştirmek gelirimi } \\
\text { artıracaktır. }\end{array}$ & 0 & 0.0 & 2 & 1.9 & 9 & 8.7 & 43 & 41.7 & 49 & 47.6 & 103 & 100.0 \\
\hline $\begin{array}{l}\text { Meyve yetiştirmek aile } \\
\text { tüketimini karşılamada } \\
\text { önemli bir kaynaktır. }\end{array}$ & 0 & 0.0 & 1 & 1.0 & 10 & 9.7 & 57 & 55.3 & 35 & 34.0 & 103 & 100.0 \\
\hline $\begin{array}{l}\text { Meyve ağacindan elde } \\
\text { edilen atıklar (budanan } \\
\text { kısımlar. kabuklar vs) } \\
\text { yakacak ihtiyacımı } \\
\text { karşımada önemlidir. }\end{array}$ & 3 & 2.9 & 4 & 3.9 & 7 & 6.8 & 53 & 51.5 & 36 & 35.0 & 103 & 100.0 \\
\hline $\begin{array}{l}\text { Meyve ağacı yetiştirmek } \\
\text { toprak verimliliğimi } \\
\text { artıracaktır. }\end{array}$ & 0 & 0.0 & 4 & 3.9 & 7 & 6.8 & 52 & 50.5 & 40 & 38.8 & 103 & 100.0 \\
\hline $\begin{array}{l}\text { Meyve ağacı yetiştirmek } \\
\text { hastalık ve zararlıların } \\
\text { yayılmasını artırır. }\end{array}$ & 0 & 0.0 & 5 & 4.9 & 12 & 11.7 & 46 & 44.7 & 40 & 38.8 & 103 & 100.0 \\
\hline $\begin{array}{l}\text { Meyve fidanlarının bakımı } \\
\text { zor olmaktadır. }\end{array}$ & 1 & 1.0 & 2 & 1.9 & 17 & 16.5 & 47 & 45.6 & 36 & 35.0 & 103 & 100.0 \\
\hline $\begin{array}{l}\text { Meyve ağaçları ürün verene } \\
\text { kadar geçen süre uzun } \\
\text { olmaktadır. }\end{array}$ & 1 & 1.0 & 1 & 1.0 & 12 & 11.7 & 46 & 44.7 & 43 & 41.7 & 103 & 100.0 \\
\hline $\begin{array}{l}\text { Meyve ağacı yetiştirmek } \\
\text { arazimde çok fazla yer } \\
\text { kaplamaktadır. }\end{array}$ & 1 & 1.0 & 4 & 3.9 & 16 & 15.5 & 38 & 36.9 & 44 & 42.7 & 103 & 100.0 \\
\hline $\begin{array}{l}\text { Meyve ağacı yetiştirmek } \\
\text { arazimde sulama suyu } \\
\text { kitlığına sebep olacaktır. }\end{array}$ & 0 & 0.0 & 10 & 9.7 & 8 & 7.8 & 38 & 36.9 & 47 & 45.6 & 103 & 100.0 \\
\hline $\begin{array}{l}\text { Meyve ağaci yetiştirmek boş } \\
\text { araziyi değerlendirmek } \\
\text { açısından önemlidir. }\end{array}$ & 1 & 1.0 & 1 & 1.0 & 14 & 13.6 & 40 & 38.8 & 47 & 45.6 & 103 & 100.0 \\
\hline
\end{tabular}




\section{Ağrı İlinde Üreticilerin Meyve Yetiştirme Kararını Etkileyen Unsurlar ve Geleceğe Yönelik Beklentileri}

Çizelge 1. Devam

\begin{tabular}{|c|c|c|c|c|c|c|c|c|c|c|c|c|}
\hline $\begin{array}{l}\text { Köydeki ürün çeşitliliğinin } \\
\text { artması benim için } \\
\text { önemlidir. }\end{array}$ & 2 & 1.9 & 1 & 1.0 & 11 & 10.7 & 42 & 40.8 & 47 & 45.6 & 103 & 100.0 \\
\hline \multicolumn{13}{|l|}{ Sübjektif Normlar } \\
\hline $\begin{array}{l}\text { Ailem meyve ağacı } \\
\text { yetiştirmem gerektiğini } \\
\text { düşünür. }\end{array}$ & 5 & 4.9 & 2 & 1.9 & 7 & 6.8 & 39 & 37.9 & 50 & 48.5 & 103 & 100.0 \\
\hline $\begin{array}{l}\text { Diğer çiftçiler meyve ağacı } \\
\text { yetiştirmem gerektiğini } \\
\text { düşünür. }\end{array}$ & 4 & 3.9 & 11 & 10.7 & 32 & 31.1 & 28 & 27.2 & 28 & 27.2 & 103 & 100.0 \\
\hline $\begin{array}{l}\text { Yayım elemanları meyve } \\
\text { ağacı yetiştirmem } \\
\text { gerektiğini düşünür. }\end{array}$ & 2 & 1.9 & 15 & 14.6 & 24 & 23.3 & 37 & 35.9 & 25 & 24.3 & 103 & 100.0 \\
\hline $\begin{array}{l}\text { Kamu kurumları meyve } \\
\text { ağacı yetiştirmem } \\
\text { gerektiğini düşünür. }\end{array}$ & 3 & 2.9 & 11 & 10.7 & 29 & 28.2 & 34 & 33.0 & 26 & 25.2 & 103 & 100.0 \\
\hline $\begin{array}{l}\text { Köyün önde gelenleri } \\
\text { meyve ağacı yetiştirmem } \\
\text { gerektiğini düşünür. }\end{array}$ & 3 & 2.9 & 19 & 18.4 & 23 & 22.3 & 37 & 35.9 & 21 & 20.4 & 103 & 100.0 \\
\hline $\begin{array}{l}\text { Köydeki çoğu } \\
\text { arazisinde } \\
\text { meyve } \\
\text { yetiştirmektedir. }\end{array}$ & 8 & 7.8 & 19 & 18.4 & 25 & 24.3 & 31 & 30.1 & 20 & 19.4 & 103 & 100.0 \\
\hline \multicolumn{13}{|l|}{ Kontrol İnançları } \\
\hline $\begin{array}{l}\text { Arazimde sık sık hastalık ve } \\
\text { zararlılarla ilgili sorun } \\
\text { yaşarım. }\end{array}$ & 2 & 1.9 & 20 & 19.4 & 29 & 28.2 & 31 & 30.1 & 21 & 20.4 & 103 & 100.0 \\
\hline $\begin{array}{l}\text { Yörede genellikle yağışlar } \\
\text { düzensiz ve yetersizdir. }\end{array}$ & 1 & 1.0 & 20 & 19.4 & 28 & 27.2 & 30 & 29.1 & 24 & 23.3 & 103 & 100.0 \\
\hline $\begin{array}{l}\text { Yörede iklim koşulları } \\
\text { meyve yetiştiriciliği için } \\
\text { uygun değildir. }\end{array}$ & 2 & 1.9 & 22 & 21.4 & 25 & 24.3 & 29 & 28.2 & 25 & 24.3 & 103 & 100.0 \\
\hline $\begin{array}{l}\text { Arazimde hayvanların } \\
\text { otlatılması riski sebebiyle } \\
\text { meyve ağacı yetiştirmek zor } \\
\text { olabilir. }\end{array}$ & 2 & 1.9 & 20 & 19.4 & 26 & 25.2 & 23 & 22.3 & 32 & 31.1 & 103 & 100.0 \\
\hline $\begin{array}{l}\text { Arazimle ilgili tüm işleri } \\
\text { yapmak için yeterli } \\
\text { zamanım var. }\end{array}$ & 1 & 1.0 & 5 & 4.9 & 31 & 30.1 & 27 & 26.2 & 39 & 37.9 & 103 & 100.0 \\
\hline $\begin{array}{l}\text { Meyve ağacı fidanlarına } \\
\text { kolayca ulaşılabilmektedir }\end{array}$ & 2 & 1.9 & 13 & 12.6 & 17 & 16.5 & 33 & 32.0 & 38 & 36.9 & 103 & 100.0 \\
\hline $\begin{array}{l}\text { Meyve bahçelerinde sulama } \\
\text { suyuna kolayca erişim } \\
\text { sağlanabilmektedir. }\end{array}$ & 3 & 2.9 & 9 & 8.7 & 14 & 13.6 & 34 & 33.0 & 43 & 41.7 & 103 & 100.0 \\
\hline
\end{tabular}




\section{Ağrı İlinde Üreticilerin Meyve Yetiştirme Kararını Etkileyen Unsurlar ve Geleceğe Yönelik Beklentileri}

Çizelge 2. Meyve ağacı yetiştirmeyenlerin Karar Almasını Etkileyen Unsurlar

\begin{tabular}{|c|c|c|c|c|c|c|c|c|c|c|c|c|}
\hline & \multicolumn{2}{|c|}{1} & \multicolumn{2}{|c|}{2} & \multicolumn{2}{|c|}{3} & \multicolumn{2}{|c|}{4} & \multicolumn{2}{|c|}{5} & \multicolumn{2}{|c|}{ Toplam } \\
\hline Subjektif İnançlar & $\mathrm{f}$ & $\%$ & $\mathrm{f}$ & $\%$ & $f$ & $\%$ & $\mathrm{f}$ & $\%$ & $\mathrm{f}$ & $\%$ & $\mathrm{f}$ & $\%$ \\
\hline $\begin{array}{l}\text { Meyve yetiştirmek gelirimi } \\
\text { artıracaktır. }\end{array}$ & 1 & 1.3 & 46 & 57.5 & 10 & 12.5 & 13 & 16.2 & 10 & 12.5 & 80 & 100.0 \\
\hline $\begin{array}{l}\text { Meyve yetiştirmek aile } \\
\text { tüketimini karşılamada } \\
\text { önemli bir kaynaktır. }\end{array}$ & 0 & 0.0 & 50 & 62.5 & 9 & 11.2 & 15 & 18.8 & 6 & 7.5 & 80 & 100.0 \\
\hline $\begin{array}{l}\text { Meyve ağacından elde edilen } \\
\text { atıklar (budanan kısımlar. } \\
\text { kabuklar vs) yakacak } \\
\text { ihtiyacımı karşımada } \\
\text { önemlidir. }\end{array}$ & 43 & 53.8 & 6 & 7.5 & 12 & 15.0 & 9 & 11.2 & 10 & 12.5 & 80 & 100.0 \\
\hline $\begin{array}{l}\text { Meyve ağacı yetiştirmek } \\
\text { toprak verimliliğimi } \\
\text { artıracaktır. }\end{array}$ & 4 & 5.0 & 44 & 55.0 & 14 & 17.5 & 9 & 11.2 & 9 & 11.3 & 80 & 100.0 \\
\hline $\begin{array}{l}\text { Meyve ağacı yetiştirmek } \\
\text { hastalık ve zararlıların } \\
\text { yayılmasını artırır. }\end{array}$ & 6 & 7.5 & 11 & 13.8 & 10 & 12.5 & 47 & 58.8 & 6 & 7.5 & 80 & 100.0 \\
\hline $\begin{array}{l}\text { Meyve fidanlarının bakımı zor } \\
\text { olmaktadır. }\end{array}$ & 0 & 0.0 & 5 & 6.2 & 10 & 12.5 & 15 & 18.8 & 50 & 62.5 & 80 & 100.0 \\
\hline $\begin{array}{l}\text { Meyve ağaçları ürün verene } \\
\text { kadar geçen süre uzun } \\
\text { olmaktadır. }\end{array}$ & 1 & 1.2 & 1 & 1.2 & 5 & 6.3 & 15 & 18.8 & 58 & 72.5 & 80 & 100.0 \\
\hline $\begin{array}{l}\text { Meyve ağacı yetiştirmek } \\
\text { arazimde çok fazla yer } \\
\text { kaplamaktadır. }\end{array}$ & 1 & 1.2 & 9 & 11.3 & 10 & 12.5 & 52 & 65.0 & 8 & 10.0 & 80 & 100.0 \\
\hline $\begin{array}{l}\text { Meyve ağacı yetiştirmek } \\
\text { arazimde } \quad \text { sulama suyu } \\
\text { kıtlığına sebep olacaktır. }\end{array}$ & 9 & 11.2 & 9 & 11.3 & 8 & 10.0 & 8 & 10.0 & 46 & 57.5 & 80 & 100.0 \\
\hline $\begin{array}{l}\text { Meyve ağacı yetiştirmek boş } \\
\text { araziyi } \\
\text { açısından önemlidir. }\end{array}$ & 0 & 0.0 & 44 & 55.0 & 8 & 10.0 & 13 & 16.2 & 15 & 18.8 & 80 & 100.0 \\
\hline $\begin{array}{l}\text { Köydeki ürün çeşitliliğinin } \\
\text { artması benim için önemlidir. }\end{array}$ & 0 & 0.0 & 46 & 57.5 & 6 & 7.5 & 20 & 25.0 & 8 & 10.0 & 80 & 100.0 \\
\hline Sübjektif Normlar & & & & & & & & & & & & \\
\hline $\begin{array}{l}\text { Ailem meyve ağacı } \\
\text { yetiştirmem gerektiğini } \\
\text { düşünür. }\end{array}$ & 45 & 56.2 & 2 & 2.5 & 12 & 15.0 & 15 & 18.8 & 6 & 7.5 & 80 & 100.0 \\
\hline $\begin{array}{l}\text { Diğer çiftçiler meyve ağacı } \\
\text { yetiştirmem gerektiğini } \\
\text { düşünür. }\end{array}$ & 50 & 62.5 & 7 & 8.8 & 10 & 12.5 & 9 & 11.2 & 4 & 5.0 & 80 & 100.0 \\
\hline $\begin{array}{l}\text { Yayım elemanları meyve } \\
\text { ağacı yetiştirmem gerektiğini } \\
\text { düşünür. }\end{array}$ & 45 & 56.2 & 7 & 8.8 & 4 & 5.0 & 18 & 22.5 & 6 & 7.5 & 80 & 100.0 \\
\hline $\begin{array}{l}\text { Kamu kurumları meyve ağacı } \\
\text { yetiştirmem gerektiğini } \\
\text { düşünür. }\end{array}$ & 41 & 51.2 & 5 & 6.2 & 8 & 10.0 & 16 & 20.0 & 10 & 12.5 & 80 & 100.0 \\
\hline $\begin{array}{l}\text { Köyün önde gelenleri meyve } \\
\text { ağac1 yetiştirmem gerektiğini } \\
\text { düşünür. }\end{array}$ & 47 & 58.8 & 10 & 12.5 & 7 & 8.8 & 10 & 12.5 & 6 & 7.5 & 80 & 100.0 \\
\hline $\begin{array}{l}\text { Köydeki çoğu kişi arazisinde } \\
\text { meyve ağacı yetiştirmektedir. }\end{array}$ & 61 & 76.2 & 7 & 8.8 & 2 & 2.5 & 6 & 7.5 & 4 & 5.0 & 80 & 100.0 \\
\hline Kontrol İnançları & & & & & & & & & & & & \\
\hline
\end{tabular}




\section{Ağrı İlinde Üreticilerin Meyve Yetiştirme Kararını Etkileyen Unsurlar ve Geleceğe Yönelik Beklentileri}

Çizelge 2. Devam

\begin{tabular}{|l|c|c|c|c|c|c|c|c|c|c|c|c|}
\hline $\begin{array}{l}\text { Arazimde sık sık hastalık ve } \\
\text { zararlılarla ilgili sorun } \\
\text { yaşarım. }\end{array}$ & 2 & 2.5 & 13 & 16.2 & 50 & 62.5 & 8 & 10.0 & 7 & 8.8 & 80 & 100.0 \\
\hline $\begin{array}{l}\text { Yörede genellikle yağışlar } \\
\text { düzensiz ve yetersizdir. }\end{array}$ & 1 & 1.2 & 1 & 1.2 & 52 & 65.0 & 9 & 11.3 & 17 & 21.2 & 80 & 100.0 \\
\hline $\begin{array}{l}\text { Yörede iklim koşulları meyve } \\
\text { yetiştiriciliği için uygun } \\
\text { değildir. }\end{array}$ & 2 & 2.5 & 6 & 7.5 & 10 & 12.5 & 14 & 17.5 & 48 & 60.0 & 80 & 100.0 \\
\hline $\begin{array}{l}\text { Arazimde hayvanların } \\
\text { otlatılması riski sebebiyle } \\
\text { meyve ağacı yetiştirmek zor } \\
\text { olabilir. }\end{array}$ & 3 & 3.8 & 6 & 7.5 & 8 & 10.0 & 13 & 16.3 & 50 & 62.5 & 80 & 100.0 \\
\hline $\begin{array}{l}\text { Arazimle ilgili tüm işleri } \\
\text { yapmak için yeterli zamanım } \\
\text { var. }\end{array}$ & 2 & 2.5 & 44 & 55.0 & 11 & 13.8 & 16 & 20.0 & 7 & 8.8 & 80 & 100.0 \\
\hline $\begin{array}{l}\text { Meyve ağacı fidanlarına } \\
\text { kolayca ulaşılabilmektedir }\end{array}$ & 8 & 10.0 & 50 & 62.5 & 6 & 7.5 & 10 & 12.5 & 6 & 7.5 & 80 & 100.0 \\
\hline $\begin{array}{l}\text { Meyve bahçelerinde sulama } \\
\text { suyuna kolayca erişim } \\
\text { sağlanabilmektedir. }\end{array}$ & 6 & 7.5 & 6 & 7.5 & 51 & 63.8 & 10 & 12.5 & 7 & 8.8 & 80 & 100.0 \\
\hline
\end{tabular}

\section{Kaynaklar}

Aktas, E., Sahin, H, Topaloğlu Z, Oledinma A, Huda A.K.S, Irani, Z., Sharif, A.M., Wout T.V., Kamvara M. (2018) A consumer behavioural approach to food waste. Journal of Enterprise Information Management 31 (5): 658-673.

Ajzen, I. (1991) The theory of planned behavior. Organ. Behav. Human Decision Process 50:179-21

Bozkurt, Ö.Ç. (2014) Planlanmış Davranış Teorisi Çerçevesinde Öğrencilerin Girişimci Olma Niyetlerinin İncelenmesi.

Ekonomi ve Yönetim Araştırmaları Dergisi 3 (1): 27-47.

Erten, S. (2002) Planlanmış Davranış Teorisi ile Uygulamalı Öğretim Metodu. Hacettepe Üniversitesi Edebiyat Fakültesi 19 (2): 217-233.

Meijer, S.S. Catacutan, D, Sileshi, GW, Nieuwenhuis, M. (2015) Tree planting by smallholder farmers in Malawi: Using the theory of planned behaviour to examine the relationship between attitudes and behaviour. Journal of Environmental Psychology 43: 1-12.

Nowak, D.J., Stein S.M., Randler, P.B., Greenfield, E.J., Comas, S.J., Carr, M.A., Alig, R.J. (2010) Sustaining America's
Urban Trees and Forests. USDA Forest Service. General Technical Report Washington, D.C.

TPO (2012) The Benefits of Trees. URL: https://treeday.planetark.org/documents/d oc-752-ntd12-the-benefits-of-trees.pdf. (Erişim tarihi: 16.07.2020)

TOB (2020) https://www.tarimorman.gov.tr/. TUIK (2020) https://www.tuik.gov.tr.

Onur, S., Kırıkc1, S. (2018) Literatür İncelemesi: Planlı Davranış Teorisi Ve Davranışsal İktisat. Social Sciences Studies Journal 4 (23): 4534-4548.

Setti, M., Falasconi, L., Segrè, A., Cusano, I., Vittuari, M. (2016) Italian Consumers' Income and Food Waste Behavior. British Food Journal 118 (7): 1731-1746.

Stefan, V., Van Herpen, E., Tudoran, A.A., Lähteenmäkia, L. (2013) Avoiding Food Waste by Romanian Consumers: The Importance of Planning and Shopping Routines. Food Quality and Preference 28: 375-381.

Yılmaz, V., Doğan, M. (2016) Planlanmış Davranıs Teorisi Kullanılarak Önerilen Bir Yapısal Eşitlik Modeli ile Geri Dönüşüm Davranışlarının Araştırılması. Anadolu Üniversitesi Sosyal Bilimler Dergisi Özel Sayıs1: 191-205. 